\title{
Implication of Paradigm Conflicts on Theory Development in Strategic Management
}

\author{
Kong-Hee Kim \\ Department of Management and Entrepreneurship \\ Herberger Business School, St. Cloud State University \\ St. Cloud, MN 56301-4498 \\ Tel: (320) 308-3911Ｆax: (320) 308-5184Ｅ-mail: kkim@stcloudstate.edu \\ James A Tan \\ Department of Management and Entrepreneurship \\ Herberger Business School, St. Cloud State University \\ St. Cloud, MN 56301-4498 \\ Tel: (320) 308-3911Ｆax: (320) 308-5184Ｅ-mail: jatan@stcloudstate.edu \\ Received: Nov. 30, 2018 Accepted: Jan. 9, $2019 \quad$ Published: January 9, 2019 \\ doi:10.5296/jmr.v11i1.14198～URL: https://doi.org/10.5296/jmr.v11i1.14198
}

\begin{abstract}
The strength of strategic management largely results from its ability to integrate diverse ideas and theories from different fields of study and apply them to real-world organizational issues. However, strategy researchers generally lack an understanding of the potential issues surrounding the paradigm conflicts that are often involved in interdisciplinary research. In response, this paper emphasizes the importance of epistemological paradigms in scientific research and discusses implications of paradigm conflicts on theory progression in strategic management. Suggestions to reduce such paradigm conflicts in interdisciplinary fertilization are also provided.
\end{abstract}

Keywords: Paradigm Conflict, Interdisciplinary Research, Strategic Management 


\section{MInstitute Macho $^{\text {Mnk }}$}

Journal of Management Research

ISSN 1941-899X

2019, Vol. 11, No. 1

Strategic management is inherently an integrative, knowledge-seeking field that draws on ideas and concepts from various scholarly disciplines such as economics, political science, sociology, and psychology. Its hallmark is the pragmatic use and integration of theories from various domains rather than relying on interdisciplinary purity (Hirsch, Friedman, \& Koza, 1990: 88). While the integration of diverse ideas and disciplines is a major strength of strategic management, it may also be a major weakness as scholars seek to unite theories and frameworks born and grown in distinctively different philosophical and methodological paradigms.

Different disciplines often have their own philosophical premises and methodological assumptions. Integration of conflicting paradigms, such as deductive positivistic empiricism and inductive organizational constructionism, may produce an abundance of trivial empirical and theoretical divergence, which hinders progress in strategic management research. So, while previous researchers have noted differences between epistemological approaches, such as empirical objectivism versus constructive subjectivism and induction versus deduction (e.g., Hirsch, Friedman, \& Koza, 1990; Lub, 2015; Shanon-Baker, 2016), strategy researchers may lack an understanding of the implications of conflicts in studies involving distinctive paradigms. Specifically, strategic management scholars may not realize the negative effects that paradigm conflicts may have on research development and theoretical progress.

Thus, the aim of this paper is to provide a discussion of the implications of paradigm conflict on theory development in strategic management and to provide suggestions for dealing with this issue. As an illustrative case, we employ agency theory in corporate governance research to show how such paradigm conflicts occur. In this way, we aim to contribute to reducing empirical and theoretical controversies and facilitate theoretical progress in strategic management.

\section{Multiple Paradigms and Paradigm Conflicts in Strategic Management}

\section{Paradigms}

Scientific research is premised upon a variety of assumptions and founded on distinct philosophical perspectives held by the researcher (Mir \& Watson, 2000). These philosophical perspectives play a role in guiding research orientations and determining what gets constructed as a research problem, theoretical procedures used, and what constitutes observations and evidence (Boyd, 1991: 22). Fundamental research orientations are linked to the epistemological research paradigm held by researchers (Arndt, 1985; Shannon-Baker, 2016) where a paradigm is a set of assumptions providing a conceptual and philosophical framework in investigating the phenomenon (Deshpande, 1983). More simply stated, a paradigm is a constellation of beliefs, values, approaches, and a set of methodologies in the process of theory evaluation and development (Kuhn, 1970). Paradigms guide researchers in determining the most important issues and the methodologies that are most appropriate in their respective disciplines (Filstead, 1979).

Paradigms develop over an extended period and are largely constructed by social processes (Collins, 1981). As a paradigm develops, it demonstrates a distinctiveness that reflects the 
perspectives and methodologies employed by the researchers in the discipline (Anderson, 1982). Thus, paradigms function in a conserving fashion (Kuhn, 1970); it shapes a researcher's scientific activities such as determining what issues and problems are viewed as important, the type of theoretical framework employed, and methodological instruments used. Such normative and conserving guidelines result in shaping the research trends in any given discipline through socialization, such as journal editing, referees, academic conferences, and career pressures (Arndt, 1985). New members of the scientific community (e.g., doctoral students) learn the details of a paradigm formally through their doctoral programs and implicitly by interacting with their social networks (Morrison, 2002).

There are two major philosophical paradigms that are embedded in the contemporary scientific community---positivistic empiricism and relativistic constructionism (e.g., Peter \& Olson, 1983; Mukhopadhyay \& Gupta, 2014; Boyd, Gove, \& Solarino, 2017). Positivistic empiricism suggests that science is an inquiry system that produces "objectively proven knowledge" (Chalmers, 1976:1), while relativistic constructionism highlights the role of the researcher in knowledge-constructing processes. Relativistic constructionism tends to conceptualize science as an organized knowledge-seeking activity whose procedures and norms are socially established (Madsen, 1974:27). Those philosophers of science favoring relativistic constructionism have suggested the concept of "incommensurability of paradigm" emphasizing the relativistic nature in the scientific inquiry process (e.g., Kuhn, 1970). Hunt (2003) argued that scientific objectivity is impossible because all knowledge claims are embedded in paradigms that are incommensurable. Thus, researchers with varying cognitive paradigms may disagree on the problems, theoretical framework, and methodological instruments to be used in the research process (Anderson, 1983). This "paradigm incommensurability" suggests that problems are likely to arise when incorporating multiple paradigms in scientific research activities, as commonly occurs in the strategic management discipline.

\section{Multiple Paradigms in Strategic Management}

Strategic management is the result of various disciplines involving multiple entities located inside and outside the organization's boundaries such as the environment, organizational actor, and resources (Hofer \& Schendel, 1978). Due to its integrative nature, the strategic management literature encompasses variety of scholarly disciplines, including economics, sociology, politics, psychology, and even music. Economic conceptions obviously maintain a prominent position in strategic management (e.g., Hirsch, Friedman, \& Koza, 1990). Modern financial economics have been employed in various strategic and organizational studies. For example, agency theory (e.g., Fama \&Jensen, 1983) is a dominant framework applied in corporate governance research, and transaction cost economics (e.g., Williamson, 1975; Ouchi, 1980) has been applied in various research contexts covering such research issues as mergers and acquisitions, firm boundaries, market expansion, and the resource-based view of the firm. In addition, theories from sociology and psychology, such as institutional framework (e.g.,DiMaggio \& Powell, 1983; Zucker, 1987), population ecology (e.g., Hannan \& Freeman, 1977), and decision making (e.g., Tversky \& Kahnemna, 1974) have had influential roles in broadening the scope of strategic management research (Hirsch et al., 1990). 


\section{NI Macrothink}

Journal of Management Research

ISSN 1941-899X

2019, Vol. 11, No. 1

Given the interdisciplinary nature of strategic management research, it is important to address the issue of multiple theoretical paradigms. Several strategy researchers have already noted the paradigmatic differences between financial economics and management (e.g., Hirsch et al., 1990). For instance, Bettis (1983) discussed how strategic management and economics use different definitions of "firm risk." Also, Hirsch et al. (1990) argued that the deductive framework in economics ignores the dynamic nature of organizational studies and suggested more tolerance for the ambiguity typically found management studies. However, little discussion has occurred in the strategic management discipline about the presence of multiple paradigms or the implications of paradigm conflicts. Specifically, a real concern should exist with strategic management researchers about the effects of paradigm conflicts on theory development and progress.

To address this, the following sections give a detailed discussion of the implications of paradigm conflict in strategic management. We would note that other areas involve similar paradigm conflicts, such as transaction cost economics (Williamson, 1975), firm risk (e.g., Bettis, 1983), corporate diversification (e.g., Rumelt, 1982), and strategic group studies (Porter, 1980). In this manuscript, we limit our arguments to discussing the use of agency theory in studies of corporate governance.

\section{Paradigm Conflict: An Illustrative Case of Agency Theory Approach to Corporate Governance Studies}

There has been much research examining corporate governance and its role in a firm's strategic success and on-going prosperity. This research is largely geared toward ensuring the effectiveness of top management through mechanisms of control and monitoring (Trickier, 2015). This has resulted on researchers relying on agency theory as the key conceptual framework. Agency theory focuses on the divergent utility functions between the principal and the agent, which is a source of agency costs for monitoring and controlling an agent's opportunistic behavior (Jensen \& Meckling, 1976). Agency theory was formulated based on the assumptions of human opportunism and maximizing gains for oneself. Corporate governance structures favor mechanisms that reduce these agency costs (Fama, 1980) and the board of directors is considered a primary mechanism for monitoring and controlling management to safeguard shareholder interests (Fama \& Jensen, 1983). As such, agency theory serves as the underlying framework in research streams such as board composition (e.g., Beatty \& Zajac, 1994; Kim \& Rasheed, 2014) and CEO duality (e.g., Rechner \& Dalton, 1991; Finkelstein \& D'Aveni, 1994; Kim, 2013).

However, these studies are characterized by competing prescriptions, mixed empirical results, and a general lack of agreement regarding agency prescriptions (Finkelstein \& D'Aveni, 1994; Denis, 2001). For example, a great deal of this research argues that CEO duality, defined as a corporate leadership structure where the same person holds both the CEO and board chairperson positions in a corporation, reduces the effectiveness of a board's function as a governance mechanism. Agency theorists argued that CEO duality promotes CEO entrenchment (e.g., Krause, Semadeni, \& Cannella, 2013) and have found that these firms have less effective board functions (Charan, 1998), higher level of bankruptcy filings (Daily \& 


\section{Ml Macrothink}

Journal of Management Research

ISSN 1941-899X

2019, Vol. 11, No. 1

Dalton, 1994), and a lower level of firm performance (Rechner \& Dalton, 1991). However, researchers holding a more organizational management perspective propose the CEO duality leadership model as a viable governance structure in corporations (e.g., Boyd, 1995). These scholars argue that a consolidated joint leadership position provides a focus for corporate leadership regarding strategic directions and implementation (Baliga \& Moyer, 1996). Their claim is that joint corporate leadership is efficient and consistent with shareholders' interest, sending a signal of managerial efficacy in obtaining firm legitimacy (e.g., Brickley, Coles, \& Jarrell, 1997).

Some empirical studies have shown a positive relationship between CEO duality and firm performance measured in financial outcomes (e.g., Boyd, 1995), while others have demonstrated no significant relationship between firm performance and the adoption of CEO duality (e.g., Brickley et al., 1997; Dalwai, Basiruddin, \& Rasid, 2015). These two competing approaches and mixed empirical findings characterize the research on CEO duality, providing ambiguous and confusing prescriptions to theorists and practitioners.

Board of director research is similarly characterized by a lack of agreement concerning boards composed of insider versus independent outsiders (e.g., Cuomo, Mallin, \& Zattoni, 2016). Researchers following agency theory suggest that insider-dominated boards are less effective in monitoring and controlling the CEO (e.g., Beatty \& Zajac, 1994). They argue that inside directors are inherently dependent on the CEO for their career advancement, and this dependence constrains the effective monitoring and controlling functions of the board (Westphal \& Zajac, 1995). Additionally, proponents of agency theory suggest that outside directors may be less conciliatory toward CEOs and more capable of resisting self-interested CEOs (Beatty \& Zajac, 1994). Alternatively, other theorists have argued that inside directors have more detailed information and expertise regarding the business and industry (e.g., Baysinger \& Hoskisson, 1990), which is advantageous to the firm when making effective strategic decisions. Outside directors, due to the lack of information and knowledge about a company's day-to-day operations, are more likely to emphasize financial measures in company performance evaluation, which may have a negative effect on new product introduction and firm adaptation (Hitt, Hoskisson, \& Ireland, 1990). When addressing the issue of board composition, agency theorists argue that powerful CEOs are more inclined to increase the socio-political closeness of the board to reduce board control and avoid power struggles (Denis, 2001).

The examples above demonstrates that corporate governance research involves two distinctive paradigms. One is the hypothetical deductive-economic perspective; the other is an inductive organizational-behavioral approach. The economic approach derives its concepts and theory from assumptions about human behavior, namely rationality and maximizing behavior (Hirsch, Friedman, \& Koza, 1990). Additionally, an economic model does not consider complex organizational and behavioral dynamics in the equation; such missing variables include "irrational" behaviors, internal politics and processes, trust, and cooperation (Bareket-Bojmel, Hochman, \& Ariely, 2017; Hirsch et al., 1990; Misangyi \& Acharya, 2014). The economic perspective places little consideration on internal organizational behaviors, simply assuming it as a contracting entity. These limitations tend to exclude many key organizational variables. 
Whereas economists view agency behavior as opportunistic, and monitoring and controlling are necessary for effectiveness, a more general management perspective views opportunism as just one of many drivers of diverse and complex behaviors.

\section{Implications of Paradigm Conflicts in Strategic Management Discipline}

Previous papers concerning the issue of paradigm differences between economic and strategic paradigms were largely developed to bridge the gap between the two disciplines (Hirsch et al., 1990) and facilitate interdisciplinary studies (Bettis, 1983). However, strategy researchers remain relatively uninformed about the implications of paradigm conflicts when doing interdisciplinary research.

Historically, philosophers have proposed diverse approaches, including logical positivism, logical empiricism, falsificationism, and relativism. These diverse streams of philosophical "isms" can be largely classified into two major philosophical approaches: positivistic empiricism and relativistic constructionism (Peter \& Olson, 1983; Merrienboer \& De Bruin, 2014). Positive empiricism posits that researchers can get close to the truth via reification of concepts and constructs and verification occurs through empirical examination (e.g., Boyd, 1991). On the other hand, relativistic constructionism suggests that the truth is contingent on specific research contexts and relative to the cognition of the researcher who perceives and interprets the phenomenon (Kuhn, 1970; Mir \& Watson, 2000).

These two philosophies address the fundamental reason for the divergence in philosophical premises (Godfrey \& Hill, 1995). Evaluating philosophical approaches is untenable because we can never be exactly sure about the objective truth (Kuhn, 1970). The use of different philosophical perspectives leads to never-ending debates in philosophy of science. Such debates include "truth versus falsity", "objectivity versus non-objectivity", and "science versus non-science" which demonstrate that these two divergent philosophical paradigms are incompatible and cannot be combined for better observation, explanation, or prediction of phenomena. As previously noted, the sociological nature of the scientific process largely determines what researchers in a field see as important and how they interpret observations (Kuhn, 1970). Research occurs in a socially-constructed community of scholarship (Mir \& Watson, 2000) and a researcher's observation and interpretation of phenomenon are always affected by preconceived notions about the nature of the problem (i.e., theory-ladenness; Feyerabend, 1975).

Thus, different philosophical paradigms, such as positivistic empiricism and relativistic constructionism, guide a researcher's choice of epistemological frameworks and the methodological instruments used in a study. Eventually, dominant methodological techniques are adopted by different philosophical paradigms. For example, the epistemological approach of positivistic empiricism is that of a quantitative paradigm and involves hypotheticaldeductive theorizing about conceptual phenomenon (Camerer, 1985). This deductive and quantitative approach provides rigorous modeling and objective predictions based on a set of assumptions. A deductionist approach enjoys predictive power of the theory, although it has been criticized for its lack of realistic validity (Camerer, 1985; Hirsch et al., 1990). To the contrary, relativistic constructionism emphasizes more value on the theory's realistic validity 
in explaining the phenomenon than its predictive ability; subsequently, relativistic constructionism prefers inductive and qualitative methods. Scientists with this philosophical stance often emphasize the discovery and generation of theories using inductive case studies and naturalistic observations (Reichardt \& Cook, 1979; Lub, 2015).

Although previous strategy researchers have noted the differences between financial economics' modeling and strategic management research (Hirsch et al., 1990; Bettis, 1983), we argue that many deductive economic concepts such as agency theory, transaction cost economics, and industrial economics are still employed in the constructionism-oriented research settings of strategic management. Such conflicts impede theoretical progress in strategic management by producing trivial theoretical and empirical differences. The point of any methodological approach is to realize the scientist's epistemological paradigm and therefore cannot be considered separately from their philosophical orientation.

Because of this, we argue despite the incommensurability of methodological paradigms positivistic empiricism is compatible with deductive/quantitative approaches. Paradigm conflict occurs when competing paradigms are included in one study. Presented as an illustrative case, many strategy researchers conceptually apply highly deductive economic models of agency theory in complex and dynamic organizational research contexts. Mixing paradigms may result in unforeseen consequences. For example, a U.S. firm whose context is based on individualism enters a collectivist market. Simply imposing current (individualistic) business practices without adapting to the market's culture may result in firm failure. Using a deductionist and quantitative approach in studying organizational dynamics such as power, politics, stewardship, agency behavior, and strategic decisions may lead to divergence of empirical evidence and theoretical arguments. Conversely, when a strategy researcher with constructionist worldview applies reductionist methodologies in research processes such as problem definition, methodology, and interpretation, difficulty will exist because of the paradigm conflicts.

Strategy researchers should be clear about their philosophical and subsequent methodological paradigms when employing theories from different backgrounds. However, we do not wish to discourage theoretical collaborations or interdisciplinary work, but rather we wish to emphasize that researchers be aware of the potential dysfunctional effects when using multiple philosophical paradigms. Consider a researcher who employs an inductive exploration method for predicting a phenomenon, or a researcher who develops a highly mechanistic model and tries to generalize it across organizational and research contexts, or a researcher seeking positivistic evidence that proves that everything is relative, or a researcher who believes in a diversity of entities and a series of complex interactions, only to pursue a simple algebraic model for predicting a phenomenon. Each of these exemplifies the problems that can and do occur, often unknown to the researcher or other scholars in the field. We suggest researchers need to be consistent in their philosophical orientation, epistemological assumptions, approaches, and goals. This further affects their choice of methodological techniques, evidence interpretation, and theory evaluation. This may be the underlying reason for many of the theoretical and empirical controversies in interdisciplinary studies. This, in turn, has crucial 
implications for the theoretical progress in the strategic management field given its inherent integrative nature.

We suggest striking a balance between philosophical approaches of positivistic empiricism and relativistic constructionism in strategic management as both are distinctive paradigms. As noted earlier, we cannot compare different philosophical approaches and judge which paradigm is superior to others; it is an epistemological worldview that underlies and guides a researcher's scientific activities. So, as long as the researcher is transparent with his/her philosophical assumptions, the researcher is producing knowledge. However, it would be more productive for researchers following relative constructionism to pursue the discovery of knowledge and the understanding organizational systems, while researchers holding more positivistic empiricism views should focus on testing of the theories developed from a relativistic constructionism approach. Positivistic research focuses on empirical examination of specific research settings as supplementary and confirmatory to inductive theories, but the key is a consistency between the epistemological perspective and methodological approaches.

In line with this argument, strategy researchers need to be aware of the relationship between philosophical perspectives and theory generalizability. Researchers pursuing generalizability across diverse contexts may adopt a positivistic-deductionist approach, having more assumptions on variables in their theory, and researchers pursuing constructive-inductionism may focus on specific research contexts emphasizing theory validity instead of theory generalizability. The point is that two divergent pursuits of external generalizability and internal theory validity are not compatible in any one study because they are competing in nature. Theory generalizability is a philosophical premise that the researcher needs to make transparent.

Strategy researchers also need to be tolerant of ambiguity concerning community consensus regarding theoretical explanations and prescriptions. The accumulation of knowledge is derived from the aforementioned philosophical streams and no single study can solve whole organizational problems; each scholar just adds a piece to the puzzle. Keeping consistency in our philosophical stances and methodological approaches is important for such theoretical progress and consensus. Because of the nature of interdisciplinary studies, we suggest that researchers be aware of the importance of paradigm conflicts when they borrow theories from different philosophical domains. Paradigm conflicts have unforeseen effects on a researcher's theory development, choice of methodological instrument, and further theory validity. Such awareness should help reduce these conflicts and help researchers develop and test more complementary theories.

\section{References}

Anderson, P. F. (1982). Current issues in the philosophy of science: Implications for marketingA panel discussion. In R. F. Bush \& S. D. Hunt (Eds.), Marketing theory: Philosophy of perspectives (pp. 11-16). Chicago, IL: American Marketing Association.

Anderson, P. F. (1983). Marketing, scientific progress, and scientific method. Journal of Marketing, 47(4), 18-31. https://dx.doi.org/10.1177/002224298304700403. 
Arndt, J. (1985). On making marketing science more scientific: Role of orientations, paradigms, metaphors, and puzzle solving. Journal of Marketing, 49(3), 11-23. https://dx.doi.org/10.1177/002224298504900302.

Baliga, B., \& Moyer, R. C. (1996). CEO duality and firm performance: What's the fuss? Strategic Management Journal, 17(1), 41-53. https://dx.doi.org/10.1002/(SICI)10970266(199601)17:1<41::AID-SMJ784>3.0.CO;2-\%23.

Bareket-Bojmel, L., Hochman, G., \& Ariely, D. (2017). It's (not) all about the Jacksons: Testing different types of short-term bonuses in the field. Journal of Management, 43, 534-554. https://dx.doi.org/10.1177/0149206314535441.

Baysinger, B., \& Hoskisson, R. E. (1990). The composition of boards of directors and strategic control: Effects on corporate strategy. Academy of Management Review, 15, 72-87. https://dx.doi.org/10.5465/amr.1990.4308231.

Beatty, R. P., \& Zajac, E. J. (1994). Managerial incentives, monitoring, and risk bearing: A study of executive compensation, ownership, and board structure in initial public offering. Administrative Science Quarterly, 39, 313-336. https://dx.doi.org/10.2307/2393238.

Bettis, R. A. (1983). Modern financial theory, corporate strategy and public policy: Three conundrums. Academy of Management Review, 8, 406-415. https://dx.doi.org/10.5465/AMR.1983.4284379

Boyd, B. K. (1991). Confirmation, semantics, and the interpretation of scientific theories, In R. Boyd, P. Gasper, \& J. D. Trout (Eds.). Philosophy of Science (pp. 3-36). Cambridge, MA: MIT Press.

Boyd, B. K. (1995). CEO duality and firm performance: A contingency model. Strategic Management Journal, 16, 301-312. https://dx.doi.org/10.1002/smj.4250160404.

Boyd, B. K., Gove, S., \& Solarino, A. M. (2017). Methodological rigor of corporate governance studies: a review and recommendations for future studies. Corporate Governance: An International Review, 25, 384-396. https://dx.doi.org/10.1111/corg.12208.

Brickley, J. A., Coles, J. L., \& Jarrell, G. A. (1997). Leadership structure: Separating the CEO and chairman of the board. Journal of Corporate Finance, 4, 189-220. https://dx.doi.org/10.1016/S0929-1199(96)00013-2.

Camerer, C. (1985). Redirecting research in business policy and strategy. Strategic Management Journal, 6, 1-15. https://dx.doi.org/10.1002/smj.4250060102.

Chalmers, A. F. (1976). What is this thing called science? St. Lucia, Australia: University of Queensland Press.

Charan, R. (1998). The board as competitive weapon: Tapping the potential. NACD Directorship, 24(5), 1-3.

Collins, H. M. (1981). Stages in the empirical programme of relativism. Social Studies of Science, 11(1), 3-10. https://dx.doi.org/10.1177/030631278101100101. 


\section{Macrothink}

Journal of Management Research ISSN 1941-899X 2019, Vol. 11, No. 1

Cuomo, F., Mallin, C., \& Zattoni. A. (2016). Corporate governance codes: A review and research agenda. Corporate governance: An International Review, 24, 222-241. https://dx.doi.org/10.1111/corg.12148.

Daily C. M., \& Dalton D. R. (1994). Bankruptcy and corporate governance the impact of board composition and structure, Academy of Management Journal, 37, 1603-1617. https://dx.doi.org/10.2307/256801.

Dalwai, T. A. R., Basiruddin, R., \& Rasid, S. Z. A. (2015). A critical review of relationship between corporate governance and firm performance: GCC banking sector perspective. Corporate Governance: The International Journal Of Business In Society, 15(1), 18-30. https://dx.doi.org/10.1108/CG-04-2013-0048.

Denis, D. K. (2001). Twenty-five years of corporate governance research ... and counting. Review of Financial Economics, 10, 191-212. https://dx.doi.org/10.1016/S10583300(01)00037-4.

Deshpande, R. (1983). "Paradigms lost": On theory and method in research in marketing. Journal of Marketing, 47(4), 101-110. https://dx.doi.org/10.1177/002224298304700411

DiMaggio, P. \& Powell, W. (1983). The iron cage revisited: Institutional isomorphism and collective rationality in organizational fields. American Sociological Review, 48,147-160. https://dx.doi.org/10.2307/2095101.

Fama, E. F. (1980). Agency problems and the theory of the firm. Journal of Political Economy, 88, 288-307. https://dx.doi.org/10.1086/260866.

Fama, E. F., \& Jensen, M .C. (1983). Separation of ownership and control. Journal of Law and Economics, 26, 301-325. https://dx.doi.org/10.1086/467037.

Feyerabend, P. K. (1975). Against method. Thetford, UK: Lowe and Brydone.

Filstead, W. J. (1979). Qualitative methods: A needed perspective in evaluation research. In T. D. Cook \& C. S. Reichardt, (Eds.), Qualitative and quantitative methods in evaluation research (pp. 33-48). Thousand Oaks, CA: Sage.

Finkelstein, S., \& D’Aveni, R. A. (1994). CEO duality as a double-edged sword: How boards of directors balance entrenchment avoidance and unity of command. Academy of Management Journal, 1078-1108. https://dx.doi.org/10.2307/256667.

Godfrey, P. C., \& Hill, C. W. L. (1995). The problem of unobservable in strategic management research. Strategic Management Journal, 16, 519-533. https://dx.doi.org/10.1002/smj.4250160703.

Hannan, M. T. \& Freeman, J. (1977). The population ecology of organizations. American Journal of Sociology, 82, 929-963. https://dx.doi.org/10.1086/226424.

Hirsch, P. M., Friedman, R., \& Koza, M. P. (1990). Collaboration of paradigm shift?: Caveat emptor and the risk of romance with economic models for strategy and policy research. Organization Science, 1, 87-97. https://dx.doi.org/10.1287/orsc.1.1.87. 
Hitt, M.A., Hoskisson, R., \& Ireland, D. (1990). Mergers and acquisitions and managerial commitment to innovation in M-Form firms. Strategic Management Journal,Special Issue: Corporate Entrepreneurship, 11, 29-47. https://www.jstor.org/stable/2486668.

Hofer, C., \& Schendel, D. (1978). Strategy formulation: Analytical concepts. St Paul, $\mathrm{MN}$ :West Publishing Co.

Hunt, S. D. (2003). Controversy in marketing theory: For reason, realism, truth, and objectivity. Armonk, NY: M. E. Sharpe.

Jensen, M. C., \& Meckling, W. H. (1976). Theory of the firm: Managerial behavior, agency costs and ownership structure. Journal of Financial Economics, 3, 305-360. https://dx.doi.org/10.1016/0304-405X(76)90026-X.

Kim, K. (2013). Deep structures in CEO duality-firm performance linkage. International Management Review, 9(2), 11-23.

Kim, K. \& Rasheed, A. A. (2014). Board heterogeneity, corporate diversification and firm performance. Journal of Management Research, 14(2), 121-139.

Krause, R., Semadeni, M., \& Cannella, A. A., Jr. (2013). CEO duality: a review and research agenda. Journal of Management, 40, 256-286. https://dx.doi.org/10.1177/0149206313503013.

Kuhn, T. S. (1970). The structure of scientific revolutions. Chicago, IL: University of Chicago Press.

Lub, V. (2015). Validity in qualitative evaluation: Linking purposes, paradigms, and perspectives. International Journal of Qualitative Methods, 14(5), 1-8. https://dx.doi.org/10.1177/1609406915621406.

Madsen, K. B. (1974). Modern theories of motivation. New York, NY: Wiley.

van Merriënboer J. J. G., \& de Bruin A. B. H. (2014). Research paradigms and perspectives on learning. In J. Spector, M. Merrill, J. Elen, \& M. Bishop (Eds.), Handbook of research on educational communications and technology (pp. 21-29). New York, NY: Springer. https://dx.doi.org/10.1007/978-1-4614-3185-5_2.

Misangyi, V., \& Acharya, A. G. (2014). Substitutes or complements? A configurational examination of corporate governance mechanisms. Academy of Management Journal, 57, 1681-1705. https://dx.doi.org/10.5465/amj.2012.0728.

Mir, R., \& Watson, A. (2000). Strategic management and the philosophy of science: The case for a constructivist methodology. Strategic Management Journal, 21, 941-953. https://dx.doi.org/10.1002/1097-0266(200009)21:9<941::AID-SMJ141>3.0.CO;2-D.

Morrison, E. W. (2002). Newcomers' relationships: The role of social network ties during socialization. Academy of Management Journal, 45, 1148-1160. https://dx.doi.org/10.5465/3069430. 


\section{Macrothink}

Journal of Management Research ISSN 1941-899X 2019, Vol. 11, No. 1

Mukhopadhyay, S., \& Gupta, R. K. (2014). Survey of qualitative research methodology in strategy research and implication for Indian researchers. Vision: The Journal of Business Perspective, 2(18), 109-123. https://dx.doi.org/10.1177/0972262914528437.

Ouchi, W. G. (1980). Markets bureaucracies and clans. Administrative Science Quarterly, 25, 129-141. https://dx.doi.org/10.2307/2392231.

Peter, J. P., \& Olson, J. C. (1983). Is science marketing? Journal of Marketing, 47(4), 111-125. https://dx.doi.org/10.1177/002224298304700412.

Rechner, P. L., \& Dalton, D. R. (1991). CEO duality and organizational performance: A longitudinal analysis. Strategic Management Journal, 12, 155-160. https://dx.doi.org/10.1002/smj.4250120206.

Reichardt, C. S., \& Cook, T. D. (1979). Beyond qualitative versus quantitative methods. In T. D. Cook \& C. S. Reichardt (Eds.), Qualitative and quantitative methods in evaluation research (pp. 7-32). Thousand Oaks, CA: Sage.

Rumelt, R. P. (1982). Diversification strategy and profitability. Strategic Management Journal, 3, 359-369. https://dx.doi.org/10.1002/smj.4250030407.

Russell, B. (1946). A history of western philosophy. New York, NY: Simon \& Schuster.

Shanon-Baker, P. (2016). Making paradigms meaningful in mixed methods research. Journal of Mixed Methods Research, 10, 319-334. https://dx.doi.org/10.1177/1558689815575861.

Trickier, B. (2015). Corporate governance: Principles, policies, and practices ( $3^{\text {rd }} \mathrm{ed}$.). Oxford, UK: Oxford University Press.

Tversky, A. \& Kahnerman, D. (1974). Judgment under uncertainty: Heuristics and biases. Science, 185(4157),1124-1131. https://dx.doi.org/10.1126/science.185.4157.1124.

Williamson, O. E. (1975). Markets and hierarchies: Analysis and antitrust implications. New York, NY: Free Press.

Zucker, L. G. (1987). Institutional theories of organization. Annual Review of Sociology, 13, 443-464. https://dx.doi.org/10.1146/annurev.so.13.080187.002303. 